\title{
Thermal refugia against coral bleaching throughout the northern Red Sea
}

\author{
Eslam O. Osman ${ }^{1,2}$ (1) David J. Smith ${ }^{1}$ (1) Maren Ziegler ${ }^{3}$ Benjamin Kürten ${ }^{3}$ \\ Constanze Conrad $^{4} \quad$ Khaled M. El-Haddad $^{5} \quad$ Christian R. Voolstra $^{3}$ (ID \\ David J. Suggett ${ }^{1,6}$ (D)
}

${ }^{1}$ Coral Reef Research Unit, School of Biological Sciences, University of Essex, Essex, UK

${ }^{2}$ Marine Biology Department, Faculty of Science, Al-Azhar University, Nasr City, Cairo, Egypt

${ }^{3}$ Red Sea Research Center, Division of Biological and Environmental Science and Engineering (BESE), King Abdullah University of Science and Technology (KAUST), Thuwal, Saudi Arabia

${ }^{4} \mathrm{MBC}-$ Marine Biology College, South Marsa Alam, Egypt

${ }^{5}$ National Institute of Oceanography and Fisheries (NIOF), Suez, Egypt

${ }^{6}$ Climate Change Cluster, University of Technology, Sydney, NSW, Australia

\section{Correspondence}

David J. Smith, Coral Reef Research Unit, School of Biological Sciences, University of Essex, Essex, UK.

Email: djsmitc@essex.ac.uk

\section{Funding information}

The Egyptian Ministry of Higher Education and Scientific Research, Cultural Affairs \& Mission sector; ARC Future Fellowship, Grant/Award Number: FT130100202; KAUST, baseline research funds; KAUST, Grant/Award Number: CCF 1973-22-01

\begin{abstract}
Tropical reefs have been impacted by thermal anomalies caused by global warming that induced coral bleaching and mortality events globally. However, there have only been very few recordings of bleaching within the Red Sea despite covering a latitudinal range of $15^{\circ}$ and consequently it has been considered a region that is less sensitive to thermal anomalies. We therefore examined historical patterns of sea surface temperature (SST) and associated anomalies (1982-2012) and compared warming trends with a unique compilation of corresponding coral bleaching records from throughout the region. These data indicated that the northern Red Sea has not experienced mass bleaching despite intensive Degree Heating Weeks (DHW) of $>15^{\circ} \mathrm{C}$-weeks. Severe bleaching was restricted to the central and southern Red Sea where DHWs have been more frequent, but far less intense (DHWs $<4^{\circ} \mathrm{C}$-weeks). A similar pattern was observed during the 2015-2016 El Niño event during which time corals in the northern Red Sea did not bleach despite high thermal stress (i.e. DHWs $>8^{\circ} \mathrm{C}$-weeks), and bleaching was restricted to the central and southern Red Sea despite the lower thermal stress (DHWs $<8^{\circ} \mathrm{C}$-weeks). Heat stress assays carried out in the northern (Hurghada) and central (Thuwal) Red Sea on four key reefbuilding species confirmed different regional thermal susceptibility, and that central Red Sea corals are more sensitive to thermal anomalies as compared to those from the north. Together, our data demonstrate that corals in the northern Red Sea have a much higher heat tolerance than their prevailing temperature regime would suggest. In contrast, corals from the central Red Sea are close to their thermal limits, which closely match the maximum annual water temperatures. The northern Red Sea harbours reef-building corals that live well below their bleaching thresholds and thus we propose that the region represents a thermal refuge of global importance.
\end{abstract}

KEYWORDS

coral bleaching, global warming, refugia, remote sensing, thermal tolerance 


\section{INTRODUCTION}

Coral bleaching is a stress response to sea surface temperature (SST) anomalies that are driven by global climate change leading to variations in regional climatology (Donner, 2011; Hoegh-Guldberg et al., 2007) and local hydrography (Weeks, Anthony, Bakun, Feldman, \& Hoegh-Guldberg, 2008). Of particular concern are El Niño-La Niña conditions that are increasing in frequency and/or duration (Cai et al., 2014) and are resulting in bleaching-induced coral mortality across regions (De'ath, Fabricius, Sweatman, \& Puotinen, 2012) and on global (Heron, Maynard, van Hooidonk, \& Eakin, 2016) scales. Anomalous temperatures as little as $1^{\circ} \mathrm{C}$ above the summer mean SST can trigger bleaching (Glynn, 1991; Goreau \& Hayes, 1994; Hoegh-Guldberg, 1999; Weeks et al., 2008); however, absolute thermal thresholds can vary across regions (e.g. $27^{\circ} \mathrm{C}$ for Rapa Nui, South Pacific vs. $36^{\circ} \mathrm{C}$ for the Arabian Gulf-see Coles \& Brown, 2003). A number of key factors, which operate in combination, ultimately determine these upper thresholds as well as how bleaching patterns manifest over space and time within any given region.

This is for several reasons. Firstly, the coral holobiont can locally adapt to specific thermal regimes via selection of more heat stress tolerant genetic variants of Symbiodinium spp. (Hume et al., 2015, 2016) and also through regulatory mechanisms of the host cnidarian itself (Barshis et al., 2013; Dixon et al., 2015) and their associated bacteria (Ziegler, Seneca, Yum, Palumbi, \& Voolstra, 2017). As such, naturally high temperature environments can retain healthy coral populations with elevated bleaching tolerances (D'Angelo et al., 2015; Oliver \& Palumbi, 2011a). Secondly, the extent of bleaching is inevitably affected by the duration (Anthony, Connolly, \& HoeghGuldberg, 2007) and periodicity (Pratchett, McCowan, Maynard, \& Heron, 2013) of SST anomalies relative to historical SST patterns (Heron et al., 2016). For example, reoccuring thermal events can increase stress tolerance (Armoza-Zvuloni, Segal, Kramarsky-Winter, \& Loya, 2011; Palumbi et al., 2014) particularly in corals with high energy reserves (Grottoli et al., 2014) and in those hosting phenotypically plastic symbionts (Ziegler, Roder, Büchel, \& Voolstra, 2015). Thirdly, thermal stress is further moderated by other environmental factors such as light intensity, salinity and nutrient concentrations (Baker, Glynn, \& Riegl, 2008; Suggett \& Smith, 2011; Wiedenmann et al., 2012). Thus, localized climatology, weather patterns and anthropogenic pressures will modify the extent of bleaching predicted by SST anomalies alone (Thompson \& van Woesik, 2009).

To understand thermal stress tolerance of corals, recent research has turned towards examining corals that are adapted to naturally high water temperature conditions. For example, corals living in back reef or reef flat habitats appear more tolerant to heat stress than corals living in adjacent systems that typically experience less temperature variability and/or lower maxima (Oliver \& Palumbi, 2011b; Schoepf, Stat, Falter, \& McCulloch, 2015). Similarly, the thermal tolerance of corals varies over large spatial scales, which is at least partly dependent on the inherent differences in ambient temperatures across sites. Corals within the Persian-Arabian Gulf (PAG) are tolerant to high water temperature $\left(36^{\circ} \mathrm{C}\right)$ compared to the global temperature average (D'Angelo et al., 2015; Hume et al., 2013) reflecting genetic adaptation of the symbionts (Hume et al., 2015; Levin et al., 2016) or host (Dixon et al., 2015; Howells, Abrego, Meyer, Kirk, \& Burt, 2016) and/or phenotypic acclimatization (Ochsenkühn, Röthig, D’Angelo, Wiedenmann, \& Voolstra, 2017; Palumbi et al., 2014).

The Red Sea is one of the world's warmest and most saline water bodies (up to $40.5 \mathrm{psu}$ ) that is populated by extensive and healthy coral reefs (see Edwards \& Head, 1986) characterized by highly similar corals assemblages along its latitudinal environmental gradients (Kürten et al., 2014; Riegl, Bruckner, Rowlands, Purkis, \& Renaud, 2012). Natural gradients of temperature, salinity and nutrient availability are a result of high evaporation, limited freshwater input and restricted water exchange with the Indian Ocean (Murray \& Johns, 1997; Sofianos \& Johns, 2003). The Red Sea has been cut off from the Indian Ocean several times when the sea level was low, causing increased water temperature and salinity (Braithwaite, 1987). Continuing today, Red Sea corals regularly experience thermal conditions predicted for most tropical reefs over the next 50 years (Grimsditch \& Salm, 2006), but yet do not appear to bleach in many locations although summer SSTs are as high as $34^{\circ} \mathrm{C}$ (Fine, Gildor, \& Genin, 2013; PERSGA, 2010). A few bleaching episodes have been recorded throughout the region (see Table S1); however, these sporadic and patchy bleaching events relative to local differences in upper thermal thresholds across environmental conditions have not been examined. Experimental evidence from the Gulf of Aqaba (Eilat) in the northern Red Sea illustrates that the local corals have surprisingly high upper thermal maxima in relation to the ambient temperatures they thrive in, and hence, this location was proposed as a natural coral refuge as SSTs continue to rise (Fine et al., 2013). Yet, the relationship between upper thermal thresholds and ambient temperatures for other coral populations across the Red Sea's large environmental gradients remains entirely unexplored (Sawall, Al-sofyani, Banguera-hinestroza, \& Christian, 2014).

Here, we investigated patterns of coral thermal sensitivity in relation to ambient temperatures across regions throughout the Red Sea. We initially compiled an extensive dataset of past coral bleaching records from throughout the Red Sea, and examined these data relative to historical SST records (1982-2012) to identify key areas least susceptible to thermal stress. We then experimentally determined coral thermal tolerance at two different latitudes with contrasting thermal histories and historical bleaching patterns (Hurghada, northern Red Sea, vs. Thuwal, central Red Sea). To verify the outcome of the historical and experimental approaches, we further examined the natural bleaching response during the 2015-2016 El Niño to test the hypothesis that coral thermal susceptibility varies between areas throughout the Red Sea. Using our unique datasets, we identified that corals in the northern Red Sea are tolerant to high thermal anomalies relative to their ambient temperature regimes, in contrast to corals in the central and southern Red Sea, which live much closer to their upper thermal threshold. As such, the entire northern Red Sea may more broadly operate as a refuge for coral populations as sea surface temperatures continue to rise. 


\section{MATERIALS AND METHODS}

\subsection{Spatial characterization of thermal history across the Red Sea (1982-2012)}

To characterize historical temperature conditions throughout the Red Sea, we selected six sites along the latitudinal axis of the Red Sea (Figure 1). Sites were chosen based on their geographical position as (1) Gulf of Aqaba (Abo Ghaloum, $28.658^{\circ} \mathrm{N}, 34.604^{\circ} \mathrm{E}$ ), (2) Gulf of Suez (Zafarana, $28.955^{\circ} \mathrm{N}, 32.668^{\circ} \mathrm{E}$ ), (3) Hurghada $\left(27.239^{\circ} \mathrm{N}, 33.862^{\circ} \mathrm{E}\right)$, (4) Wadi El Gemal (Sharm El Fukary, $24.698^{\circ} \mathrm{N}, 35.132^{\circ} \mathrm{E}$ ) in the northern Red Sea, (5) Jeddah (Thuwal, $22.234^{\circ} \mathrm{N}, 38.979^{\circ} \mathrm{E}$ ) in the central Red Sea, and (6) Farasan Island in the southern Red Sea (Farasan Island, Saudi Arabian coast, $\left.16.227^{\circ} \mathrm{N}, 42.439^{\circ} \mathrm{E}\right)$.

Weekly SST records were acquired from the Coral Reef Temperature Anomaly Database (CoRTAD) from PATHFINDER 5.2 (AVHRR$4 \mathrm{~km}$ resolution; http://data.nodc.noaa.gov/cortad/; Casey et al., 2015) for the period $1982-2012$ for a $4 \times 4 \mathrm{~km}$ grid per each site avoiding land interference. Three pre-calculated metrics were derived from CoRTAD-v5 using ARCGIS 10.3.1 software to quantify SST historical thermal stress as described in Selig, Casey, and Bruno (2010): (1) weekly SST ( ${ }^{\circ} \mathrm{C}$; i.e. the absolute weekly SST values), (2) weekly SST Anomalies (SSTA, ${ }^{\circ} \mathrm{C}$ ); i.e. deviation from the weekly SST long-term mean (1982-2012), and (3) weekly Thermal Stress Anomalies Degree Heating Weeks (TSA-DHW, ${ }^{\circ} \mathrm{C}$-weeks); i.e. the cumulative SST over a sliding window of the last 12 weeks when SST exceeded the long-term summer monthly mean by $\geq 1^{\circ} \mathrm{C}$ (Liu, Strong, Skirving, \& Arzayus, 2006). Climatology of SST was calculated as long-term monthly mean $\pm S D$ and to subsequently identify maximum/minimum climatology range (i.e. maximum summer/winter mean) and long-term seasonal variation/fluctuation (i.e. maximum minus minimum climatology) at each site. Coral bleaching thermal threshold was calculated as max climatology $+1^{\circ} \mathrm{C}$ (see Selig et al., 2010).

\subsection{Coral bleaching records (1982-2012)}

Historical bleaching data were compiled to evaluate the extent and frequency of bleaching events during the period of 1982-2012 from the following sources: (1) ReefBase database (http://www.reefbase. org/main.aspx) of bleaching severity; data deposited by both researchers and citizen scientists or acquired from published literature. This dataset provided the bleaching percentage of corals bleached at 66 surveyed sites along the Red Sea coast (1998-2010), (2) Annual Reef Check surveys $(n=188$ ) were conducted at random locations along the Egyptian Red Sea coast from 1997 to 2011. Surveys used point-intercept line transects ( $20 \mathrm{~m}$ long, $0.5 \mathrm{~m}$ interval) according to Reef Check standard protocols (Hodgson et al., 2004), and (3) Previously published papers, institutional reports and personal communications with local researchers using standard but varied techniques to quantify the percentage of corals that were bleached ( $n=10$, see Table S1).
Severity of bleaching was categorized according to Thompson and van Woesik (2009) as no bleaching $(<1 \%)$; low bleaching (1\%$10 \%$ of corals bleached); medium bleaching $(10 \%-30 \%$ of corals bleached); and high bleaching ( $>30 \%$ of corals bleached).

\subsection{Bleaching surveys of El Niño-driven thermal anomaly (2015-2016)}

The 2015/2016 El Niño thermal anomaly was extremely severe and was specifically used to verify recent coral heat stress susceptibility compared to the historical observations (1982-2012) and hence whether bleaching sensitivity varies in relation to SST anomalies among regions throughout the Red Sea. Coral bleaching surveys were conducted at sites with different thermal regimes across the northern to central-southern Red Sea during the 2015 El Niño year (from August to November). Nine near shore sites were chosen across the Red Sea spanning from 20 to $28^{\circ} \mathrm{N}$; specifically, six sites within the Gulf of Aqaba and three sites along the Saudi Arabian Red Sea coast (see Table S2). Line-intercept transects were used to quantify coral bleaching (1-3 $\mathrm{m}$ depth: see Table S2). Degree Heating Weeks for 2015 across the Red Sea was derived from NOAA Coral Reef Watch (CRW) daily global 5$\mathrm{km}$ satellite (Liu et al., 2006).

\subsection{Experimental heat stress assays}

To test the thermal tolerance of corals within the Red Sea in relation to their ambient thermal conditions, we selected two sites with different temperature regimes $\left(3.3^{\circ} \mathrm{C}\right.$ difference between sites in long-term summer monthly mean); specifically, Thuwal at the Saudi Arabian coast (Al Fahal reef, $22.2396^{\circ} \mathrm{N}, 38.9634^{\circ} \mathrm{E}$, summer temperature $=31.1 \pm 1^{\circ} \mathrm{C}$ (mean $\pm S D$ ) and Hurghada at the Egyptian coast (Abo Galawa reef, $27.3158^{\circ} \mathrm{N}, 33.8098^{\circ} \mathrm{E}$, summer temperature $=27.8 \pm 1^{\circ} \mathrm{C}$. In both regions, sampling was conducted at offshore reefs that were located away from direct anthropogenic disturbance, and had similar geomorphological characteristics and wave exposure (Fig. S1). During August and September 2013, four coral species were collected from shallow water $(2-4 \mathrm{~m}$ depth) in each region to represent the dominant growth forms of massive (Porites nodifera and Favia favus) and branching corals (Pocillopora verrucosa and Seriatopora hystrix). For each species, three replicate samples were collected from three healthy colonies (>5 $\mathrm{m}$ distance apart and randomly selected). Upon return to the laboratory, coral fragments were acclimated to the experimental conditions in outdoor shaded aquaria to reduce light stress for $48 \mathrm{hr}$ period. Tanks were filled with seawater collected directly from the native sampling sites and $\sim 70 \%$ of water was changed every $12 \mathrm{hr}$.

For experimentation, coral samples were fragmented and allocated to either heat stress or control tanks $(n=3)$ so that each experimental tank contained a single coral fragment per species. Temperature of each tank was controlled using 50w heaters (Aqua El-Neo, Poland) and measured by HOBO loggers in each tank. 

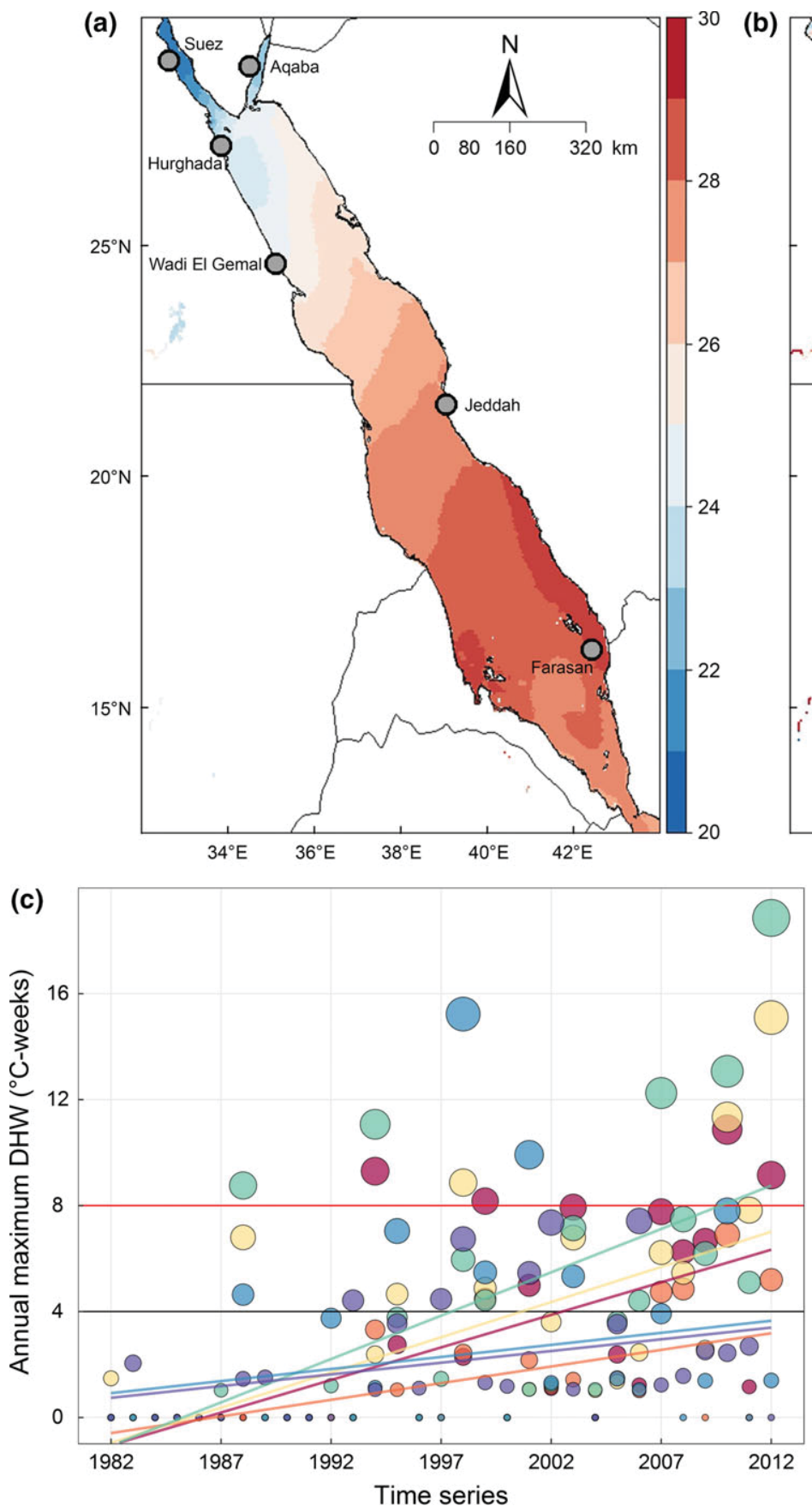
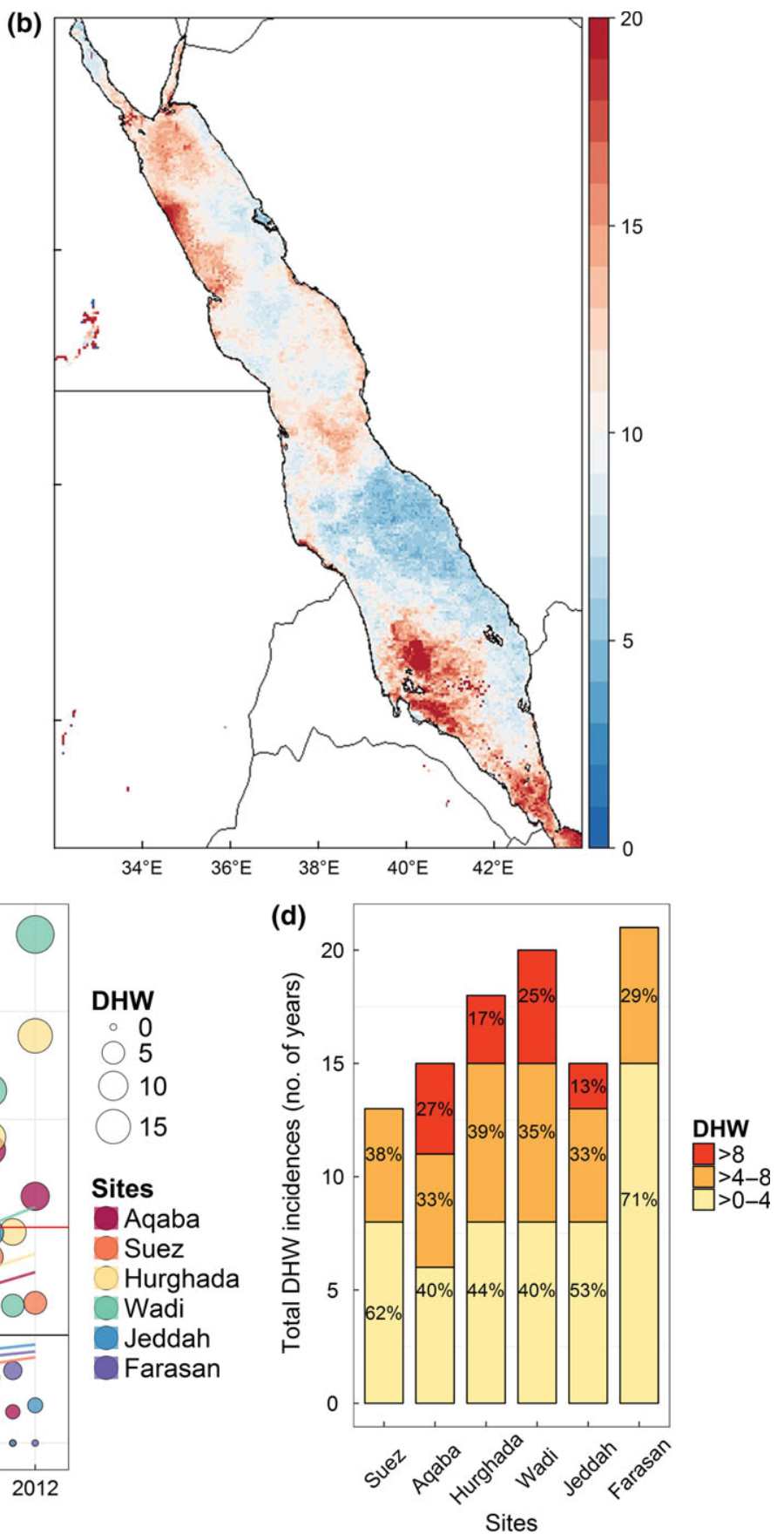

FIGURE 1 Characterization of sea surface temperature (SST) and degree heating weeks (DHWs) across the Red Sea. Maps demonstrate SST mean and maximum DHWs during the period of 1982-2012. Map of SST mean (a) shows a decline of ambient SST northward, while maximum DHW map (b) illustrates that north region is exposed to high DHWs despite its low ambient temperature. Annual maximum value of DHWs was plotted over time as sized symbol scatter plot (c) and demonstrated (1) dramatic increase in DHWs values since mid-1990s, and (2) higher trend (regression coefficient) of DHWs at the northern sites (i.e. Aqaba, Hurghada and Wadi El Gemal) than central and southern sites (i.e. Jeddah and Farasan). Reference lines were drawn (black and red lines) at 4 and $8^{\circ} \mathrm{C}$-weeks to demonstrate DHW severity, whereas DHW $>4^{\circ} \mathrm{C}$-weeks always associated with massive bleaching and $>8^{\circ} \mathrm{C}$-weeks associated with widespread mortality. Accordingly, and to quantify the intensity of DHWs at each site, maximum DHWs values were categorized into three groups; $>0-4,>4-8$ and $>8^{\circ} \mathrm{C}$-weeks for each site and plotted in the stacked bar plot (d). The bar plot illustrated high intensity of DHWs $>8^{\circ} \mathrm{C}$-weeks at the northern sites (i.e. Aqaba, Hurghada and Wadi El Gemal) of the Red Sea [Colour figure can be viewed at wileyonlinelibrary.com]

During the acclimation phase, water temperatures matched ambient temperatures at each site at the time of sampling (i.e. 26 and $30^{\circ} \mathrm{C}$ ), which were used as control temperatures during the heat stress experiment, and approximately $1.5^{\circ} \mathrm{C}$ below the long-term summer mean of 27.8 and $31.1^{\circ} \mathrm{C}$ for Hurghada and Thuwal, respectively. The heat stress treatment was set as $3^{\circ} \mathrm{C}$ above the 
long-term summer mean at Thuwal (i.e. $34.1^{\circ} \mathrm{C}$ ) to represent those temperatures that have coincided with previous reports of coral bleaching in the Red Sea (see Pilcher \& Devantier, 2000). To test the hypothesis that conspecifics corals in Hurghada (the northern Red Sea) are more thermally tolerant than corals from Thuwal (the central Red Sea), we first subjected corals to the same level of heat stress $\left(+3^{\circ} \mathrm{C}\right)$ for 5 days to $30.7^{\circ} \mathrm{C}$, then ramped up the heat stress to $6^{\circ} \mathrm{C}$ above maximum summer temperature $\left(34^{\circ} \mathrm{C}\right)$ over the remaining 5 days of the experiment. Salinity of each tank was measured twice daily and did not change over the experimental period ( $40 \pm 0.6$ psu at Hurghada and Jeddah as ambient water).

The coral bleaching response was determined through changes in photophysiological performance: (1) Rapid Light Curves (RLC) at the start and end of the experiment were performed on each coral colony independently $(n=3)$ to calculate the maximum relative Electron Transfer Rate $\left(r E T R^{\mathrm{MAX}}\right.$, $\mu$ mol electrons $\left.\mathrm{m}^{-2} \mathrm{~s}^{-1}\right)$. (2) Photochemical yields of PSII ( $F_{\mathrm{v}} / F_{m}$, dimensionless) were measured daily (30 min before sunrise) for the duration of the experiment (Diving PAM fluorometer, Walz $\mathrm{GmbH}$, Germany) and three measurements were recorded from each coral sample. All Diving PAM settings were as per Hennige et al. (2008) and any sign of coral mortality (e.g. tissue sloughing off the skeleton) was noted.

\subsection{Data analysis}

One-way ANOVA and Tukey's post hoc tests were used, after normality check using Shapiro test, to examine the spatial differences of thermal history metrics (i.e. annual mean of weekly SST, SST anomalies and annual max DHW). Generalized linear regression models (GLM) were used to determine the trend of SST annual means, SST anomalies and annual maximum DHWs over the 30-year study time period (1982-2012) at each site. To assess the extent of DHWs and how they varied over space and time, we placed all annual max DHW data from 1982 to 2012 into size bins that indicate likelihood of bleaching severity; specifically, (1) $<4^{\circ} \mathrm{C}$-weeks (considered sublethal stress and generally not resulting in bleaching), (2) significant bleaching $>4$ but $<8^{\circ} \mathrm{C}$-weeks, and (3) widespread bleaching with expected mortality at $>8^{\circ} \mathrm{C}$-weeks (Eakin et al., 2010; Liu et al., 2006). Raster maps for different SST variables/metrics were plotted directly from CoRTAD-v5 file (NetCDF format) after being cropped for the Red Sea coordinates. Mean, max and minimum values of SST were transformed from Kelvin $(\mathrm{K})$ to Celsius $\left({ }^{\circ} \mathrm{C}\right)$ degree (i.e. SST272.15).

For the heat stress assays, a Shapiro test for normality was performed and data were log-transformed if required. Two-way ANOVA analysis was performed on $r \mathrm{ETR}^{\mathrm{MAX}}$ to investigate the effect of the site and treatment on the coral's thermal tolerance, whereas oneway ANOVA was performed on $r \operatorname{ETR}^{\mathrm{MAX}}(n=3)$ to test the effect elevated temperature had on each coral species. Multifactorial repeated-measures ANOVA was performed on $F_{v} / F_{m}$ to test for the decline in maximum photochemical efficiency between control and heat-stressed groups and to measure the effect of site and species on coral thermal susceptibility. All statistics were carried out and figures produced through " $R$ " statistical software (R Development Core Team, 2015).

\section{RESULTS}

\subsection{Environmental histories across the Red Sea latitudinal gradient}

Sea surface temperature exhibited considerable variation between sites. Annual mean SST $\pm S D$ (1982-2012, $n=31$ for each site) declined significantly with increasing latitude (i.e. northwards) across the Red Sea $\left(F_{5,185}=751, p<.001\right.$; Figure 1 a, Table 1$)$ and ranged from $29 \pm 0.4^{\circ} \mathrm{C}$ at Farasan in the south to $23.6 \pm 0.6$ and $21.7 \pm 0.5^{\circ} \mathrm{C}$ at the Gulfs of Aqaba and Suez, respectively (Figure 1a, Table 1). Similarly, SST long-term summer mean (i.e. max climatology) decreased northward and declined from $31.3 \pm 1.1^{\circ} \mathrm{C}$ at Farasan to $26.6 \pm 1$ and $26 \pm 0.9^{\circ} \mathrm{C}$ at the Gulfs of Aqaba and Suez, respectively (Table 1). The warmest year throughout 19822012 for the northern Red Sea was 2010 where maximum summer temperature reached $28.8^{\circ} \mathrm{C}$ at the Gulf of Aqaba, $28^{\circ} \mathrm{C}$ at the Gulf of Suez, $29.9^{\circ} \mathrm{C}$ at Hurghada, and $31.6^{\circ} \mathrm{C}$ at Wadi El Gemal, but the central and southern Red Sea (Jeddah and Farasan) experienced highest SST during $1998-1999\left(33.7^{\circ} \mathrm{C}\right.$ and $33.9^{\circ} \mathrm{C}$, respectively, see Fig. S2), but temperatures in the south in 2010 were still comparably high $\left(32.6^{\circ} \mathrm{C}\right)$.

Annual mean SST increased over the 30-year time period for all sites and warming trends were higher compared to global averages. The warming trend was greater for the northern Red Sea despite the higher ambient temperatures in the south. Annual increase in temperature for the northern sites (Aqaba, Hurghada and Wadi El Gemal) was approximately 1.5 times that observed at the southern site (Farasan), and ranged from $0.052^{\circ} \mathrm{C} /$ year $\left( \pm 0.007, r^{2}=.65\right.$, $p<.001)$ for Aqaba to $0.02^{\circ} \mathrm{C} /$ year $\left( \pm 0.008, r^{2}=.2, p<.001\right)$ in Farasan (see Table S3, Fig. S2). Similarly, SST anomalies (i.e. SST deviation from the long-term mean) increased overtime to a greater extent (again, approximately 1.5 -fold) for the north compared to the south, and ranged from $0.05^{\circ} \mathrm{C} /$ year $\left( \pm 0.007, r^{2}=.65, p<.001\right)$ for Aqaba to $0.02^{\circ} \mathrm{C} /$ year $\left( \pm 0.008, r^{2}=.19, p<.01\right)$ in Farasan (see Table S3, Fig. S3).

Finally, the rate of change in DHWs was similar to that of SST anomalies within the Red Sea with a significant increase over time in the north, ranging from $0.25^{\circ} \mathrm{C}$-week/year $\left( \pm 0.058, r^{2}=.36\right.$, $p<.001)$ in Aqaba to $0.33^{\circ} \mathrm{C}$-week/year $\left( \pm 0.078, r^{2}=.36, p<.001\right)$ in Wadi El Gemal (Table S3), but mainly as a result of increases over the past 15 years (i.e. since mid-1990s, Figure 1c and Fig. S4). No significant increase in DHWs was observed for the central and southern sites (i.e. Jeddah and Farasan, see Figure 1c and Table S3). Importantly, whilst the frequency of DHW events was higher for the southern sites, the number of intense heating events (incidents of $>8$ DHW) was highest for the northern sites (except for Suez, see Figure 1d). Together, these data suggest that the northern Red Sea, despite its low ambient SST, has been exposed to frequent intensive 
TABLE 1 Summary of environmental variability in different study sites along the Red Sea during 1982-2012 showing annual range of SST, climatology (i.e. long-term mean) and seasonal variation (i.e. difference between minimum and maximum climatology in each site), thermal threshold (SST higher than maximum monthly mean by $1^{\circ} \mathrm{C}$ ) as well as maximum and mean of degree heat weeks (DHWs). Sites arranged from the north to the south (left to right) to show the spatial variability of SST characteristics across latitudinal gradients of the Red Sea

\begin{tabular}{llllllll}
\hline SST metrics $\left({ }^{\circ} \mathrm{C}\right)$ & Gulf of Aqaba & Gulf of Suez & Hurghada & Wadi El Gemal & Jeddah & Farasan \\
\hline Min. SST & 18.5 & 15.4 & 18.9 & 20.6 & 21 & 23.5 & 33.9 \\
\hline Max. SST & 28.8 & 28.0 & 29.9 & 31.6 & 25.7 & $28.0 \pm 0.5$ & $29.0 \pm 0.4$ \\
\hline Annual SST Mean & $23.6 \pm 0.6$ & $21.7 \pm 0.5$ & $24.7 \pm 0.5$ & $25.5 \pm 0.6$ & $22.3 \pm 0.7$ & $24.5 \pm 1.1$ & $25.8 \pm 0.8$ \\
\hline Min. Climatology & $21 \pm 0.8$ & $17.4 \pm 0.9$ & $21.8 \pm 0.9$ & 22.3 & $31.1 \pm 1$ & $31.3 \pm 1.1$ \\
\hline Max. Climatology & $26.6 \pm 1$ & $26.0 \pm 0.9$ & $27.8 \pm 1$ & $29.3 \pm 1.2$ & 7.1 & 3.5 & 5.5 \\
\hline Seasonal range & 5.6 & 8.6 & 6.0 & $28.8 \pm 1$ & $30.3 \pm 1.2$ & $32.1 \pm 1$ & $32.3 \pm 1.1$ \\
\hline Thermal threshold & $27.6 \pm 1$ & $27 \pm 0.9$ & 15.1 & 18.9 & 15.2 & 7.4 \\
\hline Max. DHW ( ${ }^{\circ}$ C-week) & 10.9 & 6.9 & $0.7 \pm 1.95$ & $0.9 \pm 2.5$ & $0.5 \pm 1.7$ & $0.5 \pm 1.3$ \\
\hline Mean DHW ( ${ }^{\circ}$ C-week) & $0.6 \pm 1.8$ & $0.3 \pm 1$ & & & &
\end{tabular}

SST anomalies (SSTA and DHW) compared to central and southern regions.

\subsection{Historical coral bleaching patterns}

Earliest reports of bleaching in 1998 were restricted to the southern and central Red Sea with ca. $30 \%$ and $60 \%$ mortality in Sudan (Pilcher \& Nasr, 2000) and Jeddah (Devantier \& Pilcher, 2000), respectively (see Table S1). No bleaching was recorded during the 1998 El Niño within the northern Red Sea despite DHWs of $>8^{\circ} \mathrm{C}$-weeks (e.g. in Hurghada and Gulf of Aqaba, see Figure 2 and Fig. S5). More recently (i.e. 2010 and 2012), bleaching has been reported within the northern and central sites (Furby, Bouwmeester, \& Berumen, 2013; Hanafy et al., 2012); however, the extent of bleaching during these events still remains low for the northern region (Figure 2) relative to the high DHWs observed (Figure 1c). For example, the Gulf of Aqaba and the Egyptian Red Sea coast did not experience mass bleaching during 2010 and 2012 despite the high DHWs, except Wadi El Gemal where 8\%19\% bleaching was observed during 2012 when DHW reached $18.9^{\circ} \mathrm{C}$-weeks (Hanafy et al., 2012). In contrast, coral reefs in the central Red Sea experienced 40\% bleaching (Furby et al., 2013) at $7.8^{\circ} \mathrm{C}$-weeks.

\subsection{Coral bleaching during the 2015/2016 El-Niño event}

Thermal anomalies in 2015 were higher in the northern region reaching 7-10.5 DHW compared to the central and southern Red Sea where DHWs remained between 0.2 and $7^{\circ} \mathrm{C}$-week (Figure 3, Table S2). Conversely, the six surveyed sites in the Gulf of Aqaba and the Egyptian Red Sea coast apparently remained without recorded bleaching (Figure 3 and Fig. S6) inspite of high DHWs $\left(>8^{\circ} \mathrm{C}\right.$-week). The bleaching was restricted to the central and southern Red Sea and was intensified southward from Yanbu (0.9\%) to Thuwal $(7.9 \%)$ to Al-Lith (99\%) despite relative lower $\mathrm{DHW}\left(<8^{\circ} \mathrm{C}\right.$ week, see Figure 3 and Fig. S6). The observed bleaching pattern

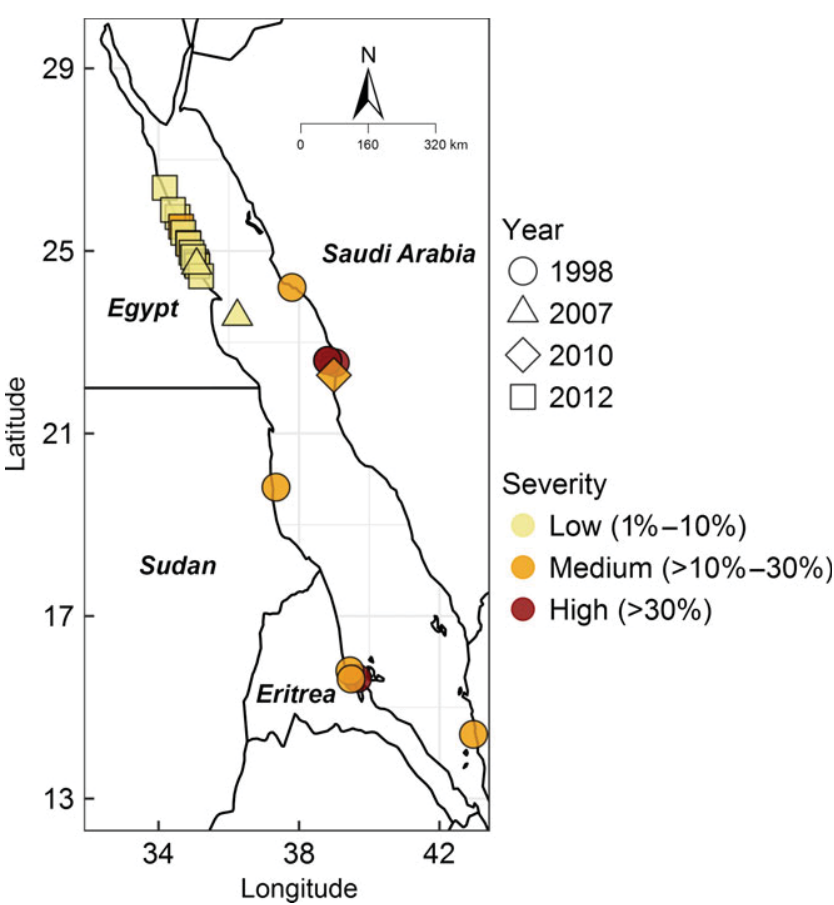

FIGURE 2 Map illustrates geographical distribution of historical corals bleaching severity along the Red Sea during the period from 1997 to 2012. Bleaching data were obtained from (1) reef check data conducted along Egyptian and Sudanese Red Sea coast, (2) ReefBase GIS database and (3) publications/reports along the Red Sea.

Unbleached sites/years were omitted for clarity (see Fig. S6). Four mass bleaching events were reported; the major bleaching event was 1998 and affected mainly the south-central region of the Red Sea (i.e. Saudi, Yemen, Djibouti and Eritrea), but no effect on the northern Red Sea was observed (Wilkinson, 2000). In contrast, recent bleaching events were observed particularly in northern and central Red Sea (i.e. Egypt and Saudi Arabia) during 2007, 2010 (Furby et al., 2013) and 2012 (Hanafy et al., 2012), but the Egyptian coast remains low in bleaching severity and the far north remained completely bleachingfree [Colour figure can be viewed at wileyonlinelibrary.com]

during 2015 was consistent with historical bleaching patterns and confirmed that corals from the northern Red Sea are consistently less sensitive to high in-situ thermal anomalies. 


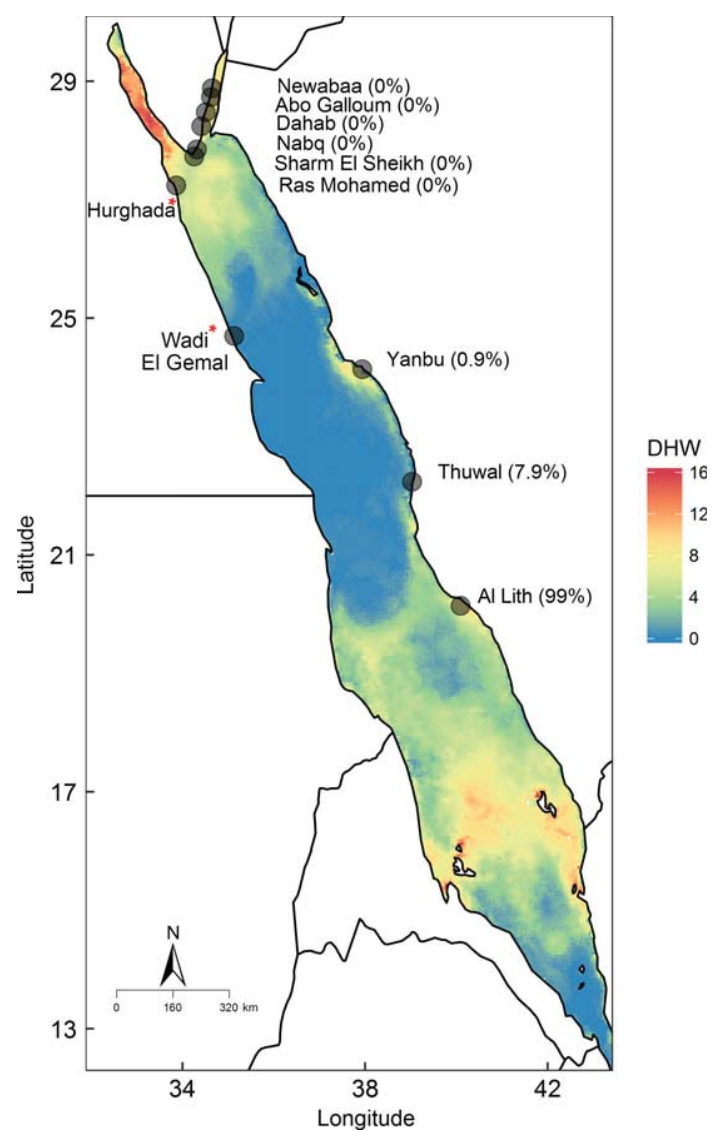

FIGURE 3 Map demonstrates maximum degree heating weeks (DHWs) in 2015 El Niño and bleaching severity throughout the Red Sea. Data were derived from NOAA Coral Reef Watch (CRW) Daily Global 5-km satellite and bleaching surveys were conducted along latitudinal gradients of the Red Sea. DHWs exhibited high values $\left(>8^{\circ} \mathrm{C}\right.$-weeks) in the southern region and the northern Red Sea including both Gulfs of Aqaba and Suez. In contrast, bleaching intensity across the latitudinal gradients (black points) showed that no bleaching was recorded in the northern Red Sea including the Gulf of Aqaba and Egyptian coast (the lack of bleaching at the two Egyptian sites was not quantitatively surveyed and denoted with red *) regardless high DHW, but high bleaching was observed in the central Red Sea and intensified southward. This supports historical and experimental findings and provides evidence that corals in the northern region are thermally tolerant and have comparably high thermal maxima relative to the ambient temperatures they experience [Colour figure can be viewed at wileyonlinelibrary.com]

\subsection{Coral heat stress assays}

Our laboratory experiments further confirmed higher coral thermal tolerance to relative increases in temperature for populations from the northern Red Sea compared to corals in the central Red Sea. Thermal stress exposure significantly affected the photophysiology of corals from Thuwal but not Hurghada. Specifically, $r$ ETR ${ }^{M A X}$ of all tested coral species (P. nodifera, F. favus, $P$. damicornis and S. hystrix) declined significantly at Thuwal $\left(F_{1,23}=25.5, p<.001\right)$ compared to Hurghada (Figure 4) after 10 days exposure up to $6^{\circ} \mathrm{C}$ above summer mean temperature. Similarly, declines in the maximum photochemical efficiency $\left(F_{v} / F_{m}\right)$ during heat stress were greater (occurred more quickly) for corals from Thuwal than for corals from Hurghada, despite species-specific patterns of susceptibility (see Fig. S7). As such, coral populations from the northern Red Sea (Hurghada) where bleaching has been less frequently recorded despite more intense DHWs (above), appear generally more thermally tolerant to increases in ambient water temperature than coral populations from the central Red Sea (Thuwal).

\section{DISCUSSION}

Thermal thresholds to bleaching-induced mortality appear highly variable within and between regions (McClanahan, Maina, MoothienPillay, \& Baker, 2005), driven predominantly through acclimatization and/or adaptation to different thermal regimes (Oliver \& Palumbi, 2011a). Our analysis demonstrated high variability of ambient temperatures across latitudinal gradients with lower ambient temperature for the northern Red Sea. Conversely, thermal anomalies (i.e. defined as DHW and SSTA) were greatest for the northern Red Sea compared to the central and southern Red Sea due to a shift of SST anomalies since approximately the mid-1990s (Figure 1c), which coincides with a general warming trend in the Red Sea (Chaidez, Dreano, Agusti, Duarte, \& Hoteit, 2017; Raitsos et al., 2011). This suggests that the northern Red Sea might be more negatively impacted by the global warming trend than the central and southern regions.

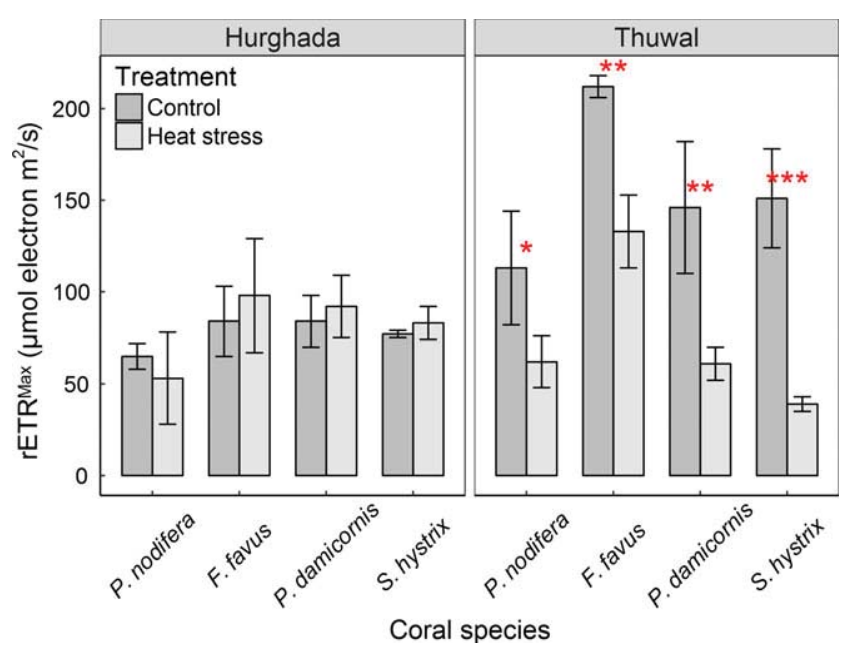

FIGURE 4 Mean $\pm S D$ of maximum relative electron transport rate ( $r$ ETR ${ }^{\mathrm{MAX}}$ ) of four coral species (Porites nodifera, Favia favus, P. damicornis and Seriatopora hystrix) after 10 days in experimental heat stress ( +3 and up to $6^{\circ} \mathrm{C}$ in Thuwal and Hurghada, respectively) in both central and northern Red Sea. Bar plot shows the difference between $r E T R^{\mathrm{MAX}}$ mean $\pm S D$ in control and treated samples for each coral species, and data revealed significant decline of $r E R^{\mathrm{MAX}}$ of treated samples in Thuwal (level of significance denoted $p<.05 *$, $.01 * *, .001 * * *)$ compared to coral species at Hurghada that showed high thermal tolerance and mean $\mathrm{rETR}^{\mathrm{MAX}}$ remained similar to controls [Colour figure can be viewed at wileyonlinelibrary.com] 
Despite the warming trend and high DHW that exceeded the global ocean warming rate $\left(0.11^{\circ} \mathrm{C}\right.$ vs. $0.5^{\circ} \mathrm{C} /$ decade in the northern Red Sea, see Heron et al., 2016), no mass bleaching observations have been recorded within the northern Red Sea region even when DHW exceeded $11^{\circ} \mathrm{C}$-weeks (Gulf of Aqaba-2010) and $15.1^{\circ} \mathrm{C}$-weeks (Hurghada-2012). Similarly, at a high $18.9^{\circ} \mathrm{C}$-weeks at Wadi El Gemal (2012), only $8 \%-20 \%$ of the coral community bleached (Hanafy et al., 2012). Such patterns clearly contrast against global bleaching incidents where mass bleaching often occurs after only $4^{\circ} \mathrm{C}$-weeks and widespread mortality at $8^{\circ} \mathrm{C}$-weeks (Eakin et al., 2010; Liu et al., 2006). This was further verified during the recent $2015 / 2016$ El Niño when DHWs were higher for the northern Red Sea where no bleaching was observed but lower in the heavily impacted areas in the south. The higher thermal tolerance of corals in relation to their ambient temperature regimes in the northern as compared to the central Red Sea was then confirmed in our heat stress assays. Together, these data extend the previous findings of high thermal tolerance of corals in the Gulf of Aqaba (Bellworthy \& Fine, 2017; Fine et al., 2013; Krueger et al., 2017) into the entire north to north-central Red Sea, increasing the potential coral reef refuge area by approximately five-fold to $24^{\circ} \mathrm{N}$ (350 km coastal line in Gulf of Aqaba vs. 1,800 km of the northern Red Sea including the Gulf of Suez).

Two potential hypotheses may explain these differential bleaching patterns within the Red Sea. Driven by the latitudinal temperature gradient, corals in the north exist at colder ambient water temperatures that are significantly lower than their thermal maxima when compared to corals in the central and southern Red Sea. Fine et al. (2013) proposed that corals were thermally selected and would thus have similar thermal thresholds throughout the Red Sea. This hypothesis was based on the premise that all present-day corals had to recolonize the Red Sea after the Last Glacial Minimum (ca. 6-7 kyr BP) and thus, recruiting larvae had to pass the $32^{\circ} \mathrm{C}$ thermal barrier at the southern entrance of the Red Sea (Braithwaite, 1987; Trommer et al., 2010). Consequently, corals that successfully recruited could have the capacity to be thermally tolerant, at least at the larval stage, to temperatures of up to $32^{\circ} \mathrm{C}$ (Fine et al., 2013). Ubiquitous coral recruitment across the Red Sea has been supported by population genetic research that demonstrated the absence of genetic variation within one of the abundant coral species $P$. verrucosa (Robitzch, Banguera-Hinestroza, Sawall, Al-Sofyani, \& Voolstra,2015), but only neutral microsatellite markers were used in this study and genome-wide evidence is needed. Fine et al. (2013) experimentally found that corals in the Gulf of Aqaba tolerated temperatures of up to $34^{\circ} \mathrm{C}$. From this evidence, Fine et al. (2013) proposed that the Gulf of Aqaba represents a coral thermal refuge. It is unclear, however, why the corals would not (at least partially) lose their high thermal tolerance after long-term exposure to the colder ambient temperatures in the northern Red Sea as was previously shown for corals in American Samoa (Palumbi et al., 2014).

Whilst we did not explicitly test the upper thermal threshold of corals in the Red Sea, outcomes of our heat stress assays are supportive of this inference, whereby corals in the northern Red Sea that were exposed up to $34^{\circ} \mathrm{C}$ for 10 days did not bleach. High relative thermal tolerance of coral species in the northern Red Sea was further confirmed during the 2015/2016 El Niño thermal anomaly when reefs in the northern region remained without detectable bleaching despite high DHWs (Figure 4). Based on our bleaching surveys and analysis of remote sensing data, we suggest that reef corals of the entire northern Red Sea, defined here as those existing between $24^{\circ} \mathrm{N}$ and $30^{\circ} \mathrm{N}$, have extraordinarily high thermal tolerances $\left(>32^{\circ} \mathrm{C}\right)$ in relation to the ambient temperatures they regularly experience $\left(26-29^{\circ} \mathrm{C}\right.$, see Table 1$)$ and are thus less susceptible to thermal anomalies. As such, our observations regionally extend the bleaching resistant coral reef area previously proposed for the Gulf of Aqaba (Fine et al., 2013). Even under an extreme scenario of IPCC (RCP-8.5) of increasing temperature anomalies by $3^{\circ} \mathrm{C}$ in 2100 , we argue that the northern Red Sea could remain free of bleaching as ambient temperatures and thermal tolerances would not overlap.

As a second hypothesis, the unique environmental features of the northern Red Sea may also reduce thermal exposure and explain the observed tolerance. The circulation pattern in the Red Sea is largely driven by atmospheric heat loss and thermohaline forces (i.e. density gradients; Sofianos \& Johns, 2007). In fact, the complex dynamical processes that generate the surface eastward flows in response to the northward pressure gradient lead to down-welling along the eastern boundary and up-welling along the western boundary (Eladawy et al., 2017; Sofianos \& Johns, 2003). Also, wind stress induces a gyre circulation pattern in the north, and a strong southward flow along the northwest coast of the Red Sea (Sofianos \& Johns, 2003; Zhai, Bower, Smethie, \& Pratt, 2015). This may reduce the influence of thermal anomalies as coral reefs in areas of high flow have been shown to be less susceptible to thermal bleaching by reducing localized build of harmful reactive oxygen species (i.e. ROS, see Nakamura, 2010; Osinga, Derksen-Hooijberg, Wijgerde, \& Verreth, 2017).

It is not possible to determine the extent to which these two hypotheses may ultimately operate (and they may not be mutually exclusive). However, it is clear that the northern region house corals that are less susceptible to the thermal anomalies experienced over the past three decades, and our data suggest that they will remain unaffected in the near future by temperature increases alone. Our data demonstrated that corals in the northern Red Sea do not follow the global stress pattern $\left(1^{\circ} \mathrm{C}\right.$ above summer temperature), unlike the central region that showed natural bleaching and significant decline in photophysiology during experimentally derived heat stress. This highlights the disconnect between the comparatively cold ambient temperature conditions in the northern Red Sea and the thermal tolerance of its corals.

Whether local acclimatization and/or adaptation have led to an increase in thermal tolerance over time remains to be assessed. Tolerance driven by past anomalies could be an adaptive or acclamatory response of the coral holobiont (Palumbi et al., 2014; Ziegler et al., 2015). Recent studies have in fact shown that there is no change in endosymbiont clade types amongst commonly encountered coral species (e.g. P. verrucosa) across the latitudinal gradient of the Red Sea (Sawall, Al-sofyani, Banguera-hinestroza, \& Voolstra, 2014; 
Ziegler, Arif, et al., 2017b); in contrast to the role of coral-associated bacteria, which may be related to the thermal tolerance of the coral host (Ziegler, Seneca, et al., 2017). The evolution of the coral holobiont in such a relatively oceanographically constrained area could have facilitated adaption and/or acclimatization (sensu Dixon et al., 2015), and a targeted functional genomics approach may be required to tease out exactly whether and how corals persist in the Red Sea with their extremely high thermal maxima. Lastly, very recent work on corals from the Persian/Arabian Gulf suggest that increased salinity, as found in the northern Red Sea in comparison to the southern Red Sea, might also be a factor that can increase stress resilience of coral holobionts by means of osmoadaptation (Ochsenkühn et al., 2017).

In conclusion, this work is the first to determine the thermal susceptibility of corals throughout the Red Sea using long-term remote sensing data, historical and contemporary ecological surveys in combination with an experimental approach. In contrast to widespread evidence from corals outside the Red Sea, our data show that regional bleaching susceptibility across the Red Sea is not aligned with the prevailing ambient SST, and we confirmed experimentally for the first time that corals in the northern Red Sea region are less susceptible to thermal stress than the corals in the central Red Sea. We therefore propose that the entire northern region to approximately $24^{\circ} \mathrm{N}(\sim 1,800 \mathrm{~km}$ coast line) may act as a refuge for reef-building corals from environmental anomalies in times of rapid climate change. Our study thus further highlights the need to regulate against local impacts that may compromise coral thermal tolerance and hence the health of reefs for the region.

\section{ACKNOWLEDGEMENTS}

This work was funded by Egyptian Ministry of Higher Education and Scientific Research, Cultural Affairs \& Mission sectors. The contribution of DJS was further supported by an ARC Future Fellowship (FT130100202). Further, research reported in this publication was supported by KAUST baseline research funds to CRV and by KAUST CCF 1973-22-01 to CRV and MZ. The authors would like to thank Red Sea National Park authority for sampling permits. Also, we acknowledge ReefBase for providing bleaching severity data. We are thankful to Prof. Mohamed Abdel Al-Wahab and Dr. Abdulaziz AlSuwailem for providing laboratory space and facilitating logistics in Hurghada and Saudi Arabia, respectively. We extend our acknowledgements to Dr. Mahmoud Maaty, Paul Müller, David Pallett and Dr. Till Röthig for help with coral sampling. Also, we thank Prof. M. M. Abou Zaid for providing unpublished reports of bleaching events from Egypt.

\section{ORCID}

Eslam O. Osman (D) http://orcid.org/0000-0002-5517-8186

David J. Smith iD http://orcid.org/0000-0003-1886-8193

Christian R. Voolstra (D) http://orcid.org/0000-0003-4555-3795

David J. Suggett iD http://orcid.org/0000-0001-5326-2520

\section{REFERENCES}

Anthony, K. R. N., Connolly, S. R., \& Hoegh-Guldberg, O. (2007). Bleaching, energetics, and coral mortality risk: Effects of temperature, light, and sediment regime. Limnology and Oceanography, 52, 716-726.

Armoza-Zvuloni, R., Segal, R., Kramarsky-Winter, E., \& Loya, Y. (2011). Repeated bleaching events may result in high tolerance and notable gametogenesis in stony corals: Oculina patagonica as a model. Marine Ecology Progress Series, 426, 149-159.

Baker, A., Glynn, P., \& Riegl, B. (2008). Climate change and coral reef bleaching: An ecological assessment of long-term impacts, recovery trends and future outlook. Estuarine, Coastal and Shelf Science, 80, 435-471.

Barshis, D. J., Ladner, J. T., Oliver, T. A., Seneca, F. O., Traylor-Knowles, N., \& Palumbi, S. R. (2013). Genomic basis for coral resilience to climate change. Proceedings of the National Academy of Sciences of the United States of America, 110, 1387-1392.

Bellworthy, J., \& Fine, M. (2017). Beyond peak summer temperatures, branching corals in the Gulf of Aqaba are resilient to thermal stress but sensitive to high light. Coral Reefs, 1-12. https://doi.org/10. 1007/s00338-017-1598-1

Braithwaite, C. (1987). Geology and paleogeography of the Red Sea region. In A. J. H. S. Edwards (Ed.), Red Sea (key environments) (pp. 22-44). Headington Hill Hall, Oxford: Pergamon Press.

Cai, W., Borlace, S., Lengaigne, M., van Rensch, P., Collins, M., Vecchi, G., ... Jin, F. (2014). Increasing frequency of extreme El Niño events due to greenhouse warming. Nature Climate Change, 4, 111-116.

Casey, K. S., Selig, E. R., Zhang, D., Saha, K., Krishnan, A., \& McMichael, E. (2015). The Coral Reef Temperature Anomaly Database (CoRTAD) Version 5 - Global, 4 km Sea Surface Temperature and Related Thermal Stress Metrics for 1982-2012 (NCEI Accession 0126774) | Dataset Overview | National Centers for Environmental Information (NCEI). Version 1.1. NOAA National Centers for Environmental Information, Dataset.

Chaidez, V., Dreano, D., Agusti, S., Duarte, C. M., \& Hoteit, I. (2017). Decadal trends in Red Sea maximum surface temperature. Scientific Reports, 7, 8144.

Coles, S. L., \& Brown, B. E. (2003). Coral bleaching - Capacity for acclimatization and adaptation. Advances in Marine Biology, 46, 183-223.

D'Angelo, C., Hume, B. C. C., Burt, J., Smith, E. G., Achterberg, E. P., \& Wiedenmann, J. (2015). Local adaptation constrains the distribution potential of heat-tolerant Symbiodinium from the Persian/Arabian Gulf. The ISME Journal, 9, 1-10.

De'ath, G., Fabricius, K. E., Sweatman, H., \& Puotinen, M. (2012). The 27-year decline of coral cover on the Great Barrier Reef and its causes. Proceedings of the National Academy of Sciences of the United States of America, 109, 17995-17999.

Devantier, L., \& Pilcher, N. (2000). The Status of Coral Reefs in Saudi Arabia - 2000. Jeddeh, pp. 1-45.

Dixon, G. B., Davies, S. W., Aglyamova, G. A., Meyer, E., Bay, L. K., \& Matz, M. V. (2015). Coral Reefs. Genomic determinants of coral heat tolerance across latitudes. Science (New York, N.Y.), 348, 1460-1462.

Donner, S. S. D. (2011). An evaluation of the effect of recent temperature variability on the prediction of coral bleaching events. Ecological Applications, 21, 1718-1730.

Eakin, C. M., Morgan, J. A., Heron, S. F., Smith, T. B., Liu, G., Alvarez-Filip, L., ... Yusuf, Y. (2010). Caribbean corals in crisis: Record thermal stress, bleaching, and mortality in 2005. PLoS ONE, 5, 1-9.

Edwards, A., \& Head, S. (1986). Red Sea key envirnment. Headington Hill Hall, Oxford, UK: Pergamon Press.

Eladawy, A., Nadaoka, K., Negm, A., Abdel-Fattah, S., Hanafy, M., \& Shaltout, M. (2017). Characterization of the northern Red Sea's oceanic features with remote sensing data and outputs from a global circulation model. Oceanologia, 59, 213-237. 
Fine, M., Gildor, H., \& Genin, A. (2013). A coral reef refuge in the Red Sea. Global Change Biology, 19, 3640-3647.

Furby, K. A., Bouwmeester, J., \& Berumen, M. L. (2013). Susceptibility of central Red Sea corals during a major bleaching event. Coral Reefs, 32, 505-513.

Glynn, P. W. (1991). Coral reef bleaching in the 1980s and possible connections with global warming. Trends in Ecology \& Evolution, 6, 175-179.

Goreau, T. J., \& Hayes, R. L. (1994). Coral bleaching and ocean "Hot Spots". Ambio, 23, 176-180.

Grimsditch, G. D., \& Salm, R. V. (2006). Coral Reef Resilience and Resistance to Bleaching. Gland, Switzerland, $52 \mathrm{pp}$.

Grottoli, A. G., Warner, M. E., Levas, S. J., Aschaffenburg, M. D., Schoepf, V., McGinley, M., ... Matsui, Y. (2014). The cumulative impact of annual coral bleaching can turn some coral species winners into losers. Global Change Biology, 20, 3823-3833.

Hanafy, M. H., Ismail, M., Agnese, M., Yousef, M., Nagm, M., \& ELSadek, I. (2012). A Preliminary report on: The 1st Mass Bleaching Event for the Egyptian Reefs of the Red Sea. Egypt, 23 pp.

Hennige, S. J., Smith, D. J., Perkins, R., Consalvey, M., Paterson, D. M., \& Suggett, D. J. (2008). Photoacclimation, growth and distribution of massive coral species in clear and turbid waters. Marine Ecology Progress Series, 369, 77-88.

Heron, S. F., Maynard, J. A., van Hooidonk, R., \& Eakin, C. M. (2016). Warming trends and bleaching stress of the world's coral reefs 1985-2012. Scientific Reports, 6, 38402.

Hodgson, G., Kiene, W., Mihaly, J., Liebeler, J., Shuman, C., \& Maun, L. (2004). Reef Check Instruction Manual: A Guide to Reef Check Coral Reef Monitoring. Institute of the Environment, University of California at Los Angeles, 79 pp.

Hoegh-Guldberg, O. (1999). Climate change, coral bleaching and the future of the world's coral reefs. Mar. Freshwater Res., 50, 839-866.

Hoegh-Guldberg, O., Mumby, P. J., Hooten, A. J. J., Steneck, R. S., Greenfield, P., Gomez, E., ... Hatziolos, M. E. E. (2007). Coral reefs under rapid climate change and ocean acidification. Science, 318, 17371742.

Howells, E. J., Abrego, D., Meyer, E., Kirk, N. L., \& Burt, J. A. (2016). Host adaptation and unexpected symbiont partners enable reef-building corals to tolerate extreme temperatures. Global Change Biology, 22, 2702-2714.

Hume, B. C. C., Angelo, C. D., Smith, E. G., Stevens, J. R., Burt, J., \& Wiedenmann, J. (2015). Symbiodinium thermophilum sp. nov., a thermotolerant symbiotic alga prevalent in corals of the world's hottest sea, the Persian/Arabian Gulf. Scientific Reports, 5, 8562.

Hume, B., D'Angelo, C., Burt, J., Baker, A. C., Riegl, B., \& Wiedenmann, J. (2013). Corals from the Persian/Arabian Gulf as models for thermotolerant reef-builders: Prevalence of clade C3 Symbiodinium, host fluorescence and ex situ temperature tolerance. Marine Pollution Bulletin, 72, 313-322.

Hume, B. C. C., Voolstra, C. R., Arif, C., D'Angelo, C., Burt, J. A., Eyal, G., .. Wiedenmann, J. (2016). Ancestral genetic diversity associated with the rapid spread of stress-tolerant coral symbionts in response to Holocene climate change. Proceedings of the National Academy of Sciences of the United States of America, 113, 4416-4421.

Krueger, T., Meibom, A., Horwitz, N., Bodin, J., Giovani, M.-E., Escrig, S., \& Fine, M. (2017). Common reef-building coral in the Northern Red Sea resistant to elevated temperature and acidification. Royal Society Open Science, 4, 170038.

Kürten, B., Al-Aidaroos, A. M., Struck, U., Khomayis, H. S., Gharbawi, W. Y., \& Sommer, U. (2014). Influence of environmental gradients on C and $\mathrm{N}$ stable isotope ratios in coral reef biota of the Red Sea, Saudi Arabia. Journal of Sea Research, 85, 379-394.

Levin, R. A., Beltran, V. H., Hill, R., Kjelleberg, S., McDougald, D., Steinberg, P. D., \& van Oppen, M. J. H. (2016). Sex, scavengers, and chaperones: Transcriptome secrets of divergent symbiodinium thermal tolerances. Molecular Biology and Evolution, 33, 3032.
Liu, G., Strong, A., Skirving, W., \& Arzayus, L. (2006). Overview of NOAA coral reef watch program's near-real time satellite global coral bleaching monitoring activities. In: Proceedings of the 10th international coral ..., Vol. 1, pp. 1783-1793. Okinawa, Japan.

McClanahan, T. R., Maina, J., Moothien-Pillay, R., \& Baker, A. C. (2005). Effects of geography, taxa, water flow, and temperature variation on coral bleaching intensity in Mauritius. Marine Ecology Progress Series, 298, 131-142.

Murray, S. P., \& Johns, W. (1997). Direct observations of seasonal exchange through the Bab el Mandab Strait. Geophysical Research Letters, 24, 2557-2560.

Nakamura, T. (2010). Importance of water-flow on the physiological responses of reef-building corals. Galaxea, Journal of Coral Reef Studies, 12, 1-14.

Oliver, T. A., \& Palumbi, S. R. (2011a). Many corals host thermally resistant symbionts in high-temperature habitat. Coral Reefs, 30, 241-250.

Oliver, T. A., \& Palumbi, S. R. (2011b). Do fluctuating temperature environments elevate coral thermal tolerance? Coral Reefs, 30, 429-440.

Osinga, R., Derksen-Hooijberg, M., Wijgerde, T., \& Verreth, J. A. J. (2017). Interactive effects of oxygen, carbon dioxide and flow on photosynthesis and respiration in the scleractinian coral Galaxea fascicularis. Journal of Experimental Biology, 220, 2236-2242.

Palumbi, S. R., Barshis, D. J., Traylor-Knowles, N., Bay, R. A., Hoegh-Guldberg, O., Hughes, T. P., ... Willis, B. (2014). Mechanisms of reef coral resistance to future climate change. Science (New York, N.Y.), 344, 895-898.

PERSGA (2010). Status of coral reefs in the Red Sea and Gulf of Aden: 2009. PERSGA Technical Series Number 16, Jeddah, 125 pp.

Pilcher, N., \& Devantier, L. (2000). The status of coral reefs in Yemen 2000. 1-47.

Pilcher, N., \& Nasr, D. (2000). The status of coral reefs in Sudan - 2000. $1-29$.

Pratchett, M. S., McCowan, D., Maynard, J. A., \& Heron, S. F. (2013). Changes in bleaching susceptibility among corals subject to ocean warming and recurrent bleaching in Moorea, French Polynesia. PLOS ONE, 8, e70443.

R Development Core Team (2015). R: A language and environment for statistical computing. Vienna, Austria: R Foundation for Statistical Computing, 1, 409.

Raitsos, D. E., Hoteit, I., Prihartato, P. K., Chronis, T., Triantafyllou, G., \& Abualnaja, Y. (2011). Abrupt warming of the Red Sea. Geophysical Research Letters, 38, L14601.

Riegl, B. M., Bruckner, A. W., Rowlands, G. P., Purkis, S. J., \& Renaud, P. (2012). Red sea coral reef trajectories over 2 decades suggest increasing community homogenization and decline in coral size. PLoS ONE, 7, e38396.

Robitzch, V., Banguera-Hinestroza, E., Sawall, Y., Al-Sofyani, A., \& Voolstra, C. R. (2015). Absence of genetic differentiation in the coral Pocillopora verrucosa along environmental gradients of the Saudi Arabian Red Sea. Frontiers in Marine Science, 2, 1-10.

Sawall, Y., Al-sofyani, A., Banguera-hinestroza, E., \& Voolstra, C. R. (2014). Spatio-temporal analyses of Symbiodinium physiology of the coral Pocillopora verrucosa along large-scale nutrient and temperature gradients in the Red Sea. Photobiology, 9, 1-12.

Schoepf, V., Stat, M., Falter, J. L., \& McCulloch, M. T. (2015). Limits to the thermal tolerance of corals adapted to a highly fluctuating, naturally extreme temperature environment. Scientific Reports, 5, 17639.

Selig, E. R., Casey, K. S., \& Bruno, J. F. (2010). New insights into global patterns of ocean temperature anomalies: Implications for coral reef health and management. Global Ecology and Biogeography, 19, 397411.

Sofianos, S. S., \& Johns, W. E. (2003). An Oceanic General Circulation Model (OGCM) investigation of the Red Sea circulation: 2. Three- 
dimensional circulation in the Red Sea. Journal of Geophysical Research, 108, 1-15.

Sofianos, S. S., \& Johns, W. E. (2007). Observations of the summer Red Sea circulation. Journal of Geophysical Research, 112, C06025.

Suggett, D. J., \& Smith, D. J. (2011). Interpreting the sign of coral bleaching as friend vs. foe. Global Change Biology, 17, 45-55.

Thompson, D. M., \& van Woesik, R. (2009). Corals escape bleaching in regions that recently and historically experienced frequent thermal stress. Proceedings of the Royal Society of London B: Biological Sciences, 276, 2893-2901.

Trommer, G., Siccha, M., Rohling, E. J., Grant, K., Van Der Meer, M. T. J., Schouten, S., ... Kucera, M. (2010). Millennial-scale variability in Red Sea circulation in response to Holocene insolation forcing. Paleoceanography, 25, PA3203.

Weeks, S. J., Anthony, K. R. N., Bakun, A., Feldman, G. C., \& Hoegh-Guldberg, O. (2008). Improved predictions of coral bleaching using seasonal baselines and higher spatial resolution. Limnology and Oceanography, 53, 1369-1375.

Wiedenmann, J., D'Angelo, C., Smith, E. G., Hunt, A. N., Legiret, F.-E., Postle, A. D., \& Achterberg, E. P. (2012). Nutrient enrichment can increase the susceptibility of reef corals to bleaching. Nature Climate Change, 3, 160-164.

Wilkinson, C. (2000). Status of coral reefs of the world: 2000. Townsville, Qld: Australian Institute of Marine Science.

Zhai, P., Bower, A. S., Smethie, W. M., \& Pratt, L. J. (2015). Formation and spreading of Red Sea outflow water in the Red Sea. Journal of Geophysical Research: Oceans, 120, 6542-6563.
Ziegler, M., Arif, C., Burt, J. A., Dobretsov, S., Roder, C., LaJeunesse, T. C., \& Voolstra, C. R. (2017). Biogeography and molecular diversity of coral symbionts in the genus Symbiodinium around the Arabian Peninsula. Journal of Biogeography, 44, 674-686.

Ziegler, M., Roder, C., Büchel, C., \& Voolstra, C. (2015). Niche acclimatization in Red Sea corals is dependent on flexibility of host-symbiont association. Marine Ecology Progress Series, 533, 149-161.

Ziegler, M., Seneca, F. O., Yum, L. K., Palumbi, S. R., \& Voolstra, C. R. (2017). Bacterial community dynamics are linked to patterns of coral heat tolerance. Nature Communications, 8, 14213. 